smelted bronze. Here, no doubt, we have the stockin-trade of some travelling Bronze Age tinker collecting scrap and perhaps casting new types of tools -new lamps for old! Naturally, the date when the hoard was collected or abandoned cannot have been earlier than that of the most recent tools it contains, and these would suggest that the tinker plied his trade in the Late Bronze Age.

Such 'hoards' have been found before in Kent. The largest and most important is the so-called Minster hoard of no fewer than 143 objects, which included socketed and winged celts, swords, spearheads, palstaves, a sickle, a knife, scrap metal, etc. Other well-known ones have been discovered at Allhallows, Broadness, Cliffe, Morden, Saltwood, Sittingbourne, Stoke, Swalecliffe and the Isle of Harty. Kent was an important part of the country in the Late Bronze Age, suffering as it then did from continental invasions which must have made life somewhat unsettled. Perhaps this is why comparatively little domestic pottery of the period has turned up. On the other hand foreign contacts did lead to an enrichment of the material culture of the district. It is perhaps noteworthy that the dead were disposed of by cremation, the ashes being placed in pottery urns which were deposited in pits dug in the ground and covered over by round tumuli.

\section{Luminous Strontium Sulphide}

THE usefulness of most forms of phosphorescent paint is limited by the rapid decay in luminosity when exposed in the dark. A new preparation with an appreciably longer useful luminous glow has recently been marketed ; the phosphorescent material is luminous strontium sulphide, which is applied over an undercoat of titanium oxide. The makers are British Luminous Industries, Ltd., London, N.W.10. Apart from the many obvious uses in the 'black-out' (signs and markings would be quite invisible at any distances to which aircraft might approach), it is suggested that the application of this material to the ceilings of shelters and public buildings would provide illumination in the event of the failure of the normal lighting. The luminosity immediately after activation is so strong that this suggestion seems practicable.

\section{Theodor Ritter von Oppolzer (r84I-I886)}

ON October 26 occurred the centenary of the birth of the Austrian astronomer Theodor Ritter von Oppolzer who from 1876 until his death on December 26, 1886, held the chair of astronomy at Vienna. Born at Prague, he was the only son of Johann von Oppolzer, (1808-71), a well-known pathologist who held chairs first in Prague, then in Leipzig and Vienna. Though he took a degree in medicine, Theodor von Oppolzer, being of independent means, devoted his time to astronomy and built a private observatory. For ten years he studied asteroids and comets, on which" he published a well-known "Lehrbuch". In 1873 he became connected with the great European degree measurement, and for some years was chairman of the Austrian Commission. In his later years he studied planetary disturbances, the motion of the moon, refraction and other subjects. His most notable contribution to science, however, was his "Canon der Finsterniss”", containing the elements of eclipses of the sun and moon, some 13,000 in number, from 1207 B.C. to A.D. 2162 (1887). Among the honours he received were his election as an associate of the Royal Astronomical Society and as a corresponding member of the Paris Academy of Sciences. His son Egon (1869-1907) was an assistant at Prague Observatory and professor extraordinary at Innsbruck.

\section{Ages of American Men of Science}

IN view of the comments on the present-day status of youth in science, beginning on p. 511 of this issue, the analysis of the ages of men of science on the U.S. National Roster of Scientific and Specialized Personnel presented by Dr. L. Carmichael, president of Tufts College and director of the Roster, to the American Psychological Association is of interest. More than one fourth of the first sixty thousand men of science listed on the Roster are less than thirty years of age. More than half are less than forty. Only a fifth are more than fifty. The total on the Roster now is more than 180,000 . The Roster is the reservoir of scientific and other personnel in the United States for the defence programme, and is similar to the Central Register of Great Britain.

\section{Recent Earthquakes}

The U.S. Coast and Geodetic Survey, in co-operation with Science Sэrvice and the Jesuit Seismological Association, has determined the tentative epicentres of four recent earthquakes from reports received from seismograph stations. On August 2 the earthquake at 11h. $41 \cdot 5 \mathrm{~m}$. U.T. had its epicentre near latitude $30^{\circ} \mathrm{S}$., longitude $178 \cdot 5^{\circ} \mathrm{W}$. This is in the Pacific Ocean just west of the Kermadec Islands and the Aldrich Deep so that the suggested depth of focus of $100 \mathrm{~km}$. is not unusual. Deep-focus earthquakes are frequent in this area. The earthquake of August 4 at 10 h. 53m. U.T. probably had its epicentre near latitude $52^{\circ} \mathrm{N}$., longitude $176.5^{\circ} \mathrm{W}$., which is in the north Pacific Ocean near Adak Island of the Aleutian Islands group. The depth of focus of $100 \mathrm{~km}$. was somewhat unusual for the district though it was exceeded by as much as $100 \mathrm{~km}$. by the earthquake of August 6 at $6 \mathrm{~h} \cdot 15 \cdot 3 \mathrm{~m}$. U.T. The epicentre of this latter shock was on the Alaska Peninsula. On August 15 the earthquake at $6 \mathrm{~h} .9 \cdot 5 \mathrm{~m}$. U.T. probably had its epicentre near latitude $19^{\circ} \mathrm{N}$., longitude $27^{\circ} \mathrm{W}$., which is in the Atlantic Ocean north-west of St. Vincent of the Cape Verde Islands. As all these shocks had epicentres distant from human habitation no damage has been reported, but had they been near centres of population they would undoubtedly have been strong enough to cause considerable damage.

During the first fortnight of September, eight large distant earthquakes were registered at Kow Observatory. All gave a full suite of pulses, the greatest being on September 9 . This started recording with a probable $i P K P$ wave (compressional) at 7 h. 38m. 52s. U.T. from a calculated epicentre distant 